\title{
When infection threats the mind: an investigation into the cognitive impairment associated with HIV infection
}

\author{
Quando a infecção ameaça a mente: uma investigação sobre \\ a deterioração cognitiva associada à infecção pelo HIV
}

Miguel Bragança

Doutorado (Neurociências Clínicas) na Faculdade de Medicina da Universidade do Porto, 2012, Porto, Portugal.

Orientador: Professor Doutor António Pacheco Palha.

Correspondence: Miguel Ângelo Bragança; Rua Quinta das Chãs 218 / casa 40; 4400-556 Vila Nova de Gaia - Portugal; E-mail: miguelbraganca@netcabo.pt

\begin{abstract}
Introduction: Researchers have observed a clear increase in the incidence and prevalence of neurocognitive disorders associated with human immunodeficiency virus (HIV) infection due to early involvement of the central nervous system. Objectives: It was find predictors of cognitive deterioration of a set of variables related to sociodemographic, lifestyle, comorbid depression and disease progression. Methods: One hundred and thirty (130) HIV-positive outpatients, asymptomatic, with undetectable viral load, CD 4 count $>200$ cells/mm ${ }^{3}$, treated with combined antiretroviral therapy (CART). In addition to the structured interview and clinical global assessment, they were administered the Hamilton Rating Scale for Depression (HAM-D) and the HIV Neurobehavioral Research Center Battery, consisting of 16 neuropsychological tests. Results: A positive relation between cognitive impairment and depression was found, although it has not shown determinant of the overall neurocognitive damage. The negative impact of infection on neurocognition was confirmed, globally and in all areas evaluated. The main predictors of cognitive functioning were: (1) education, professional status and social class; (2) infection pathway, protective measures and lifestyles; (3) psychotropic drugs and coffee intake; (4) disease stage and nadir CD4 count. Conclusions: Strategies for prevention and treatment of cognitive impairment should take into account several levels of intervention, leading to an earlier treatment with cART.
\end{abstract}

Key words: neuropsychological functioning, cognition disorder, depression, Psychiatry, HIV/AIDS. 